УДК 577.2

DOI: 10.33184/spbgb-2021-09-21.13

\title{
Мелатонин снижает токсичность меди для растений огурца
}

\author{
() И.Ф. Головацкая, Р.А. Городова, Е.В. Бойко, И.Н. Плюснин, М.К. Кадырбаев \\ Национальный исследовательский Томский государственный университет \\ Россия, 634050, г. Томск, пр. Ленина, 36 \\ *Email: golovatskaya.irina@mail.ru
}

Для повышения устойчивости растений огурца к действию высокой концентрации меди предложена методика обработки их семян или корней раствором мелатонина низкой концентрации.

Ключевые слова: Cucumis sativus, мелатонин, медь, прорастание семян, рост и развитие растений, фотосинтетические пигменты, перекисное окисление липидов, устойчивость к тяжёлым металлам

В настоящее время одной из причин ухудшения качественного состава почв и воды является загрязнение их тяжелыми металлами (ТМ). Активное поглощение ТМ растениями и последующее накопление их вдоль пищевой цепи создаёт потенциальную угрозу для здоровья человека. Представителем ТМ является медь, которая служит важным микроэлементом для растений, регулируя окислительно-восстановительные процессы [1-3]. Она играет существенную роль в процессах дыхания, поскольку входит в состав цитохромоксидазы, аскорбиноксидазы и полифенолоксидазы. Медь также участвует в синтезе хлорофилла, в световой стадии фотосинтеза на уровне ЭТЦ в составе медьсодержащего белка - пластоцианина. Она регулирует сигналинг гормонов, входя в состав рецептора этилена. Однако при высоких концентрациях медь является опасным фритотоксикантом, снижающим активность и биосинтез ряда ферментов. Переизбыток этого элемента может провоцировать десрицит железа в растениях.

Среди фракторов эндогенной регуляции и управления в растительном организме выделяют фритогормоны. Изначально обнаруженный у животных и человека мелатонин относят к гормонам, регулирующим циркадные ритмы, сезонную репродуктивную фризиологию организмов, иммунитет и др. $[2,4,5]$. У растений показано присутствие мелатонина и зависимость его уровня от абиотических и биотических негативных факторов среды. На сегодняшний день окончательно не установлена гормональная функция для фритомелатонина, поскольку последняя требует наличия сигналинга, в том числе его рецепции в клетках. Несмотря на это, показано участие мелатонина в таких процессах, как рост, ризогенез и фотосинтез $[2,4,5]$. Он снижает токсическое воздействие различных тяжелых металлов [2].

В настоящее время востребовано изучение физиолого-генетических аспектов устойчивости растений к действию ТМ, поскольку это способствует созданию генетического банка устойчивости культурных растений к ТМ и разработке способов повышения их продуктивности и получения экологически чистой растительной продукции.

Целью данного исследования стало изучение протекторного действия мелатонина на морфофизиологические процессы растений огурца в условиях повышенной концентрации ионов меди. 
Объектом исследования служили проростки огурца Cucumis sativus L. сорта Изящный, выведенного во ВНИИССОК селекционером О.В. Юриной и в 1971 году включенного в Госреестр России.

В ходе исследования изучали влияние разных концентраций ионов меди и мелатонина в среде на энергию прорастания и всхожесть семян, размеры и строение структурных элементов проростков огурца, содержание фотосинтетических пигментов, окислительный статус.

Эксперимент проводили в асептических условиях, начиная от стерилизации семян огурца до автоклавирования среды культивирования. Семена проращивали в водных растворах смеси меди и мелатонина разных концентраций. В качестве контрольной среды служил водный раствор, содержащий 12,5 мкг/л 5-водного медного купороса или 3,2 мкг/л ионов меди, что было аналогично его количеству в 50\% среде Мурасиге-Скуга (MC). В качестве опыта брали широкий диапазон концентраций ионов меди (от 6,4 до 80,0 мкг/л), что позволило определить степень устойчивости данного сорта огурца к микроэлементу. Для оценки протекторного действия мелатонина на растения были выбраны 100-кратно различающиеся его концентрации (10 пМ и 1 нМ). Для анализа морфологических и биохимических параметров проводили эксперимент с сокращённым диапазоном концентраций ионов меди (от 3,2 до 16,0 мкг/л). Для этого 5-дневные проростки огурца, перешедшие на фототрофный тип питания, переносили из водных растворов на 50 \%-ную питательную среду МС, содержащую 3,2 мкг/л ионов меди (контроль) и МС с добавлением разных концентраций ионов меди и мелатонина (опыт) и культивировали в течение 4 суток в условиях осветительной установки при 16 ч фотопериоде на свету с интенсивностью 150 мкмоль фотонов/ ${ }^{2}$ с при температуре $22,0 \pm 2,0^{\circ} \mathrm{C}$.

В результате исследования установлено, что действие меди на процессы в зародышах семян и проростках огурца зависело от её концентрации в питательной среде. Увеличение концентрации ионов меди в растворе в 2-5 раз снижало энергию прорастания (3 сутки) и всхожесть семян (5 сутки) (рис. 1), тогда как в 10-25 раз - полностью тормозило (последние данные не приведены).

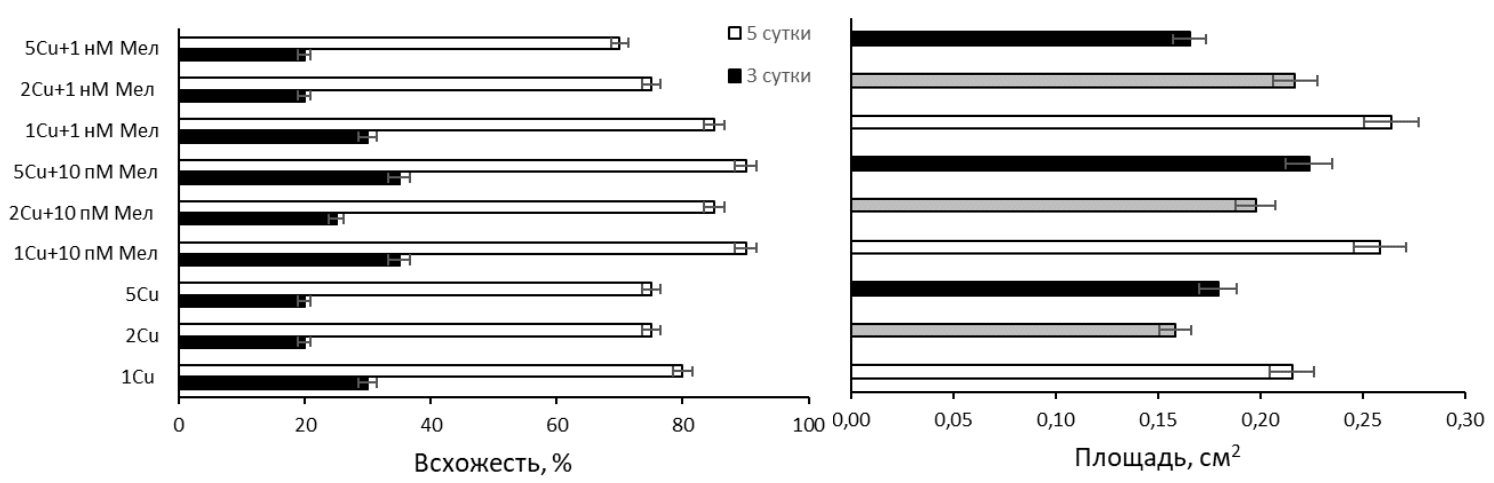

Рис. 1. Зависимость энергии прорастания семян (3 сутки), их всхожести (5 сутки) и площади семядолей проростков (9 сутки) от концентрации меди (Cu) и мелатонина (Мел) в среде: индекс при Сu показывает кратность увеличения концентрации относительно контроля. 
Добавление мелатонина в медь-содержащую 50\% питательную среду МС повышало как энергию прорастания, так и всхожесть семян огурца. Наиболее высокая всхожесть семян наблюдалась при действии мелатонина низкой концентрации 10 пМ. Возможно, это связано с воздействием мелатонина на растяжение клеток зародыша, т.е. осуществлением им гормональной функции при минимальных концентрациях. Результаты согласуются с нашими данными по взаимодействию индоламина с ИУК при растяжении клеток колеоптиля. Именно низкие концентрации мелатонина с ИУК обеспечивают наибольший ростовой эфффект [4]. В нашем исследовании добавление экзогенного мелатонина привело к повышению выживаемости проростков, что вероятно было обусловлено его протекторным действием. Негативное действие высоких концентраций 32 - 80 мкг/л ионов меди 1,0 нМ мелатонин не смог снять (данные не приведены).

Изучение медь-зависимой регуляции морфогенеза проростков показало, что повышение уровня меди в среде приводило к уменьшению ветвления корней и их размеров, укорочению стебля и площади семядолей и в результате к уменьшению биомассы проростков (рис. 1, рис. 2 а-в). В противоположность действию меди, мелатонин увеличивал длину и ветвление корней, а также площадь поверхности семядолей и соответственно биомассу проростков (рис. 1, рис. 2 г).



Рис. 2. Внешний вид 9-дневных проростков огурца, культивированных на среде МС+3,2 мкг/л Сu (а, контроль), МС+6,4 мкг/л Сu (б), МC+16,0 мкг/л Сu (в) и МС+3,2 мкг/л Сu+10 пМ мелатонин (г).

Наибольшее содержание сухого вещества и наименьшее содержание воды было обнаружено у проростков огурца контрольного варианта и составило 14,5 и 85,5\% соответственно. 2-кратное увеличение концентрации меди в среде приводило к повышению воды в проростках. Это могло быть связано с повышением осмотического давления в клетке за счёт ионов меди и сульфата и активного притока воды. В тоже время 5кратное увеличение концентрации меди снижало и биомассу и содержание воды, что могло быть обусловлено негативным действием меди на функциональную активность клеток. Добавление экзогенного 10 пМ мелатонина в среду повышало содержание воды в растениях всех вариантов, тогда как 1 нМ мелатонина - уровень воды повышался только при норме меди. Эфрфективность мелатонина снижалась при действии больших концентраций экзогенной меди.

Анализ сформированности фотосинтетического аппарата проводили по уровню фотосинтетических пигментов и площади семядолей (см рис. 1) растений огурца. Установ- 
лено, что при 2-кратном увеличении концентрации экзогенной меди происходило снижение содержания Хл а и каротиноидов по сравнению с контролем. Добавление мелатонина в контрольную среду повышало содержание зелёных пигментов в семядолях, при низкой концентрации мелатонина - Хл $b$, а при высокой - Хл а. Протекторное действие мелатонина с повышением уровня меди (6,4 и 16,0 мкг/л) проявилась только при увеличении его концентрации до 1 нМ. При этом восстанавливался уровень Хл $b(6,4$ мкг/л), Хл а и каротиноидов (16,0 мкг/л) (данные не приведены).

Окислительный статус структурных элементов проростков огурца зависел от их функциональной активности (рис. 3). Независимо от варианта опытных растений в корне и семядолях перекисное окисление липидов (ПОЛ) было выше, чем в стебле. Увеличение уровня ионов меди до 16.0 мкг/л в среде снизило интенсивность ПОЛ в корне (белые столбцы). Добавление мелатонина низкой концентрации во всех 3-х вариантах меди увеличивало интенсивность ПОЛ. Основным источником АФК в корне служит дыхание, поэтому с увеличением его интенсивности могли быть связаны эффректы мелатонина. Повышение концентрации мелатонина до 1 нМ снизила интенсивность ПОЛ, что согласуется с его антиоксидантными свойствами.

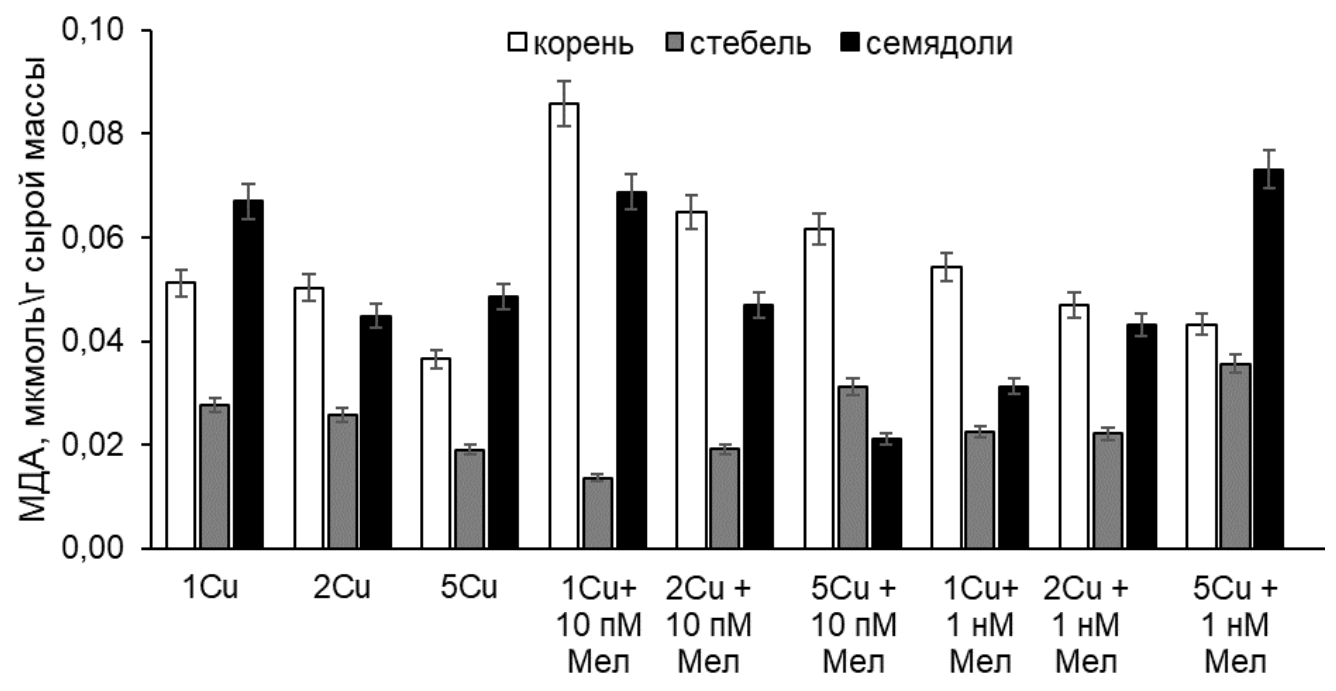

Рис. 3. Зависимость интенсивности перекисного окисления структурных элементов проростка огурца от концентрации меди $(\mathrm{Cu})$ и мелатонина (Мел) в среде.

В отличие от корня в семядолях (черные столбцы) интенсивность ПОЛ начинала снижаться при действии более низких концентраций ионов меди (6,4 мкг/л). Основываясь на известных фрактах об источниках АФК в семядолях - дыхания и фотосинтеза, можно предположить снижение интенсивности этих процессов под действием меди. 1 нM мелатонин снижал негативный эффект 5-кратного уровня меди в семядолях, что сопровождалось повышением интенсивности ПОЛ, вероятно вызванной интенсификацией процессов фотосинтеза [5]. В варианте с контрольным уровнем меди эта концентрация мелатонина проявляла антиоксидантные свойства. Разные ответные реакции корня и семядолей на одни и те же концентрации меди и мелатонина вероятно связаны с их доступностью и органоспецифричными фрункциями.

Совокупность представленных данных позволяет сделать вывод о том, что уже 2кратное увеличение концентрации ионов меди относительно уровня в среде МС в присутствии сульфат-ионов оказывала негативное действие на ростовые и физиологиче- 
ские характеристики растений огурца, и свидетельствовало о высокой чувствительности к меди растений огурца на начальных этапах онтогенеза. Экзогенный мелатонин снижал повреждающее действие меди. Степень протекторного действия мелатонина зависела от его концентрации и интенсивности стресс-фактора. Для повышения устойчивости растений огурца к действию повышенной концентрации меди в почве или воде может быть предложена обработка их семян или корней раствором мелатонина низкой концентрации.

\title{
Литература
}

1. Кушнарева О.П., Перекрестова Е.Н. Влияние различных концентраций солей меди и свинца на содержание хлорофилла и содержание углерода в листьях растений // Вестник Оренбургского государственного университета. 2015. № 10 (185). С. 294-297.

2. Холодова В.П., Васильев С.В., Ефимова М.В., Воронин П.Ю. Рахманкулова З.Ф., Данилова Е.Ю., Кузнецов Вл.В. Экзогенный мелатонин защищает растения рапса от токсического действия избытка меди // Физиология растений. 2018. Т. 65. № 6. С. 463471. DOI: $10.1134 / \mathrm{S} 0015330318060088$

3. Головацкая И.Ф., Кабил Ф., Когай В., Кайлер О.А., Нечаева М.В., Гавенко А.А., Гурина Е.В. Устойчивость растений-регенерантов Solanum tuberosum к ионам меди in vitro // Актуальные проблемы картофрелеводства: фрундаментальные и прикладные аспекты: материалы Всерос. науч.-практ. конф. с междунар. участием, 10-13 апр. 2018 г. Томск: Издательский Дом ТГУ, 2018. С. 40-45.

4. Головацкая И.Ф., Бойко Е.В., Карначук Р.А. Роль мелатонина в регуляции ИУКзависимых реакций растений в разных условиях освещения // Вестник Томского государственного университета. Биология. 2017. №37. С. 144-160. DOI: $10.17223 / 19988591 / 37 / 8$

5. Бойко Е.В., Головацкая И.Ф., Бендер О.Г., Плюснин И.Н. Влияние кратковременной корневой обработки мелатонином на фотосинтез листьев огурца // Физиология растений. 2020. T. 67, № 2. C. 196-205. DOI: 10.31857/S0015330320020037

\section{Melatonin reduces copper toxicity to cucumber plants}

\author{
I.F. Golovatskaya*, R.A. Gorodova, E.V. Boyko, I.N. Plyusnin, M.K. Kadyrbaev \\ National Research Tomsk State University, 3640 Lenin Ave., Tomsk, 634050 Russia \\ *Email: golovatskaya.irina@mail.ru
}

We increased the resistance of cucumber plants to a high concentration of copper by treating seeds or roots with a low concentration of melatonin.

Keywords: Cucumis sativus, melatonin, copper, seed germination, plant growth and development, photosynthetic pigments, lipid peroxidation, resistance to heavy metals. 